\title{
A mão e a luva: a respeito de um soneto escrito por Jorge de Lima
}

\section{MirelLa MÁrCiA LONGO ${ }^{I}$}

I

NTEGRANDO uma leitura do Livro de sonetos (Lima, 1958, p.565-605) escrito pelo poeta alagoano Jorge de Lima, a análise que se segue contempla o $37^{\circ}$ poema do conjunto. O texto faz parte de um grupo centrado no contato com a bem-querida. ${ }^{l}$ Iniciada no $33^{\circ}$ poema do livro, a série estende-se até o $49^{\circ}$.

Convulsionado pelo segundo conflito mundial do século XX e pelas crises que vieram em seguida, o contexto histórico que abrigou a composição do Livro de sonetos, fornecendo talvez o pathos agônico e a natureza dissolvente de muitas imagens, representaria, aos olhos do poeta, uma culminância da perda de vida tratada em seus versos como declínio, desânimo e neles associada ao motivo bíblico da Queda. É possível identificar, ao longo dos 78 sonetos, um deslocamento subjetivo - desde o estado de angústia e agonia, constante nos poemas iniciais, até a atitude de confiança exposta no final. Inserido nesse quadro mais amplo, o contato com a amada parece essencial à busca de uma revitalização que deve, pela linguagem, atingir a história.

A hipótese norteadora da leitura identifica, no Livro de sonetos, uma crítica à modernidade laica cuja cultura, centrada na ideia de que Deus está morto, teria perdido contato com forças capazes de insuflar vida. Habitante dessa cultura, o poeta distanciado da fonte vital, a sua bem-querida, move-se amorosamente para encontrá-la. Se a tradição laica opera um corte entre o inconsciente e a transcendência, Jorge de Lima concebe que, coincidindo à psique, a bem-querida constitui porta aberta a um mundo arquetípico e transcendente. Em larga medida, a amada entra em conexão com a anima, tal como pensada por Jung: “imagem da alma”, "arquétipo da própria vida”, "personificação de um componente da psique".

Considerada uma via de acesso ao mistério transcendente, a referência feminina constante nos poemas de Jorge de Lima tem vasto alcance simbólico. Ela é também a natureza, a imaginação, a força inspiradora e, como poema, constitui glosa à Graça. A bem-querida é sono e também insânia. Embora seja fonte de vida, é feita de imaterialidade e, por isso, pertence ao mundo da noite, da música e da morte. Penetrar na dimensão dessa amada é abismar-se na própria interioridade e nela encontrar a reminiscência das coisas eternas. Capaz de 
transformar as imagens do mundo subjetivo, o contato amoroso com a própria alma promove, no âmbito do livro publicado em 1949, novos nascimentos para o poeta e para o mundo.

\section{Uma luva inerte no vento}

Trigésimo sétimo poema contido no Livro de sonetos, o texto a seguir transcrito focaliza primordialmente a "mulher que morre", imagem que dá acesso à bem-querida, tal como uma luva feita de matéria sensível pode nos fazer captar a mão imaterial a que se ajusta completamente.

E esse vento indo e vindo pela porta, e o ambiente se diluindo, se diluindo, e com ele o crepúsculo. Olhai bem que a mão pendida se assemelha a uma

tombada luva branca, luva morta (luva inerte no vento). O rosto lindo começou a esvair-se e inda contém a delícia da vida que se esfuma.

Mas ninguém sabe se esse vento quando passa gemendo pela sala obscura e vai esconder-se em seu cabelo ruivo,

se é o hálito de Deus ou antes o uivo das potências adversas à criatura umas e outras sem trégua dialogando. (Lima, 1958)

Quatro elementos estão configurados com nitidez; são eles: o vento, a força mais ativa no conjunto; o ambiente e o crepúsculo que evidenciam estar sob o signo da passagem; e uma figura humana que, com acentuado caráter de visão, acompanha o processo geral, sem deixar de exibir beleza e também o único sinal de inércia existente em meio à dinâmica delineada pelo contínuo esmaecimento que arrasta para o fim todas as formas.

O primeiro verso do soneto destaca a ação do vento, em movimentos de idas e vindas. Em contraste com a enunciação do elemento potente que, realizando o avanço, é também capaz de executar movimento em sentido contrário, os dois versos seguintes falam do ambiente e do crepúsculo avançando, continuamente e sem retorno, num processo de diluição que só lhes pode conduzir ao próprio fim. Essa dissolvência parece atingir proporções cósmicas, pois, abrangendo o ambiente humano limitado pela porta, abarca também a natureza, representada por um crepúsculo que se desfaz. 
Pela insistência com que repetem a mesma sílaba tônica em indo, vindo, diluindo e diluindo, os versos iniciais evocam o som do vento, ativo, em meio ao quadro de entrega passiva ao destino letal. Em seu constante ir e vir, o vento fica excluído do quadro composto por elementos em ininterrupta diluição. Consequentemente, ele deve ser visto como representação de uma força que, resistindo à morte, manifesta-se em meio à existência a ela destinada.

O quarto verso tem seu ritmo quebrado pela voz poética que, usando o modo imperativo adequado às profecias, posiciona o leitor diante de uma visão em cujo centro instala-se a figura humana também entregue à morte. O lugar ocupado pelo poema na sequência dedicada à bem-querida indica que se trata de uma mulher. ${ }^{2} \mathrm{O}$ primeiro terceto mencionará o cabelo, mas, tal como surge, iniciada nos dois últimos versos da primeira estrofe e desenvolvida na segunda, a composição da figura concentra-se na mão pendida e consolida-se com a qualificação do rosto.

Conotando queda, ausência de sangue, de vida e de movimento, os quatro atributos da luva - tombada, branca, morta e inerte no vento - contaminam a mão que pende e todo o corpo, do qual essa mão constitui metonímia poderosa. Essas qualidades intensificam fortemente o decréscimo de vitalidade indicado na própria analogia estabelecida entre a mão e um objeto inanimado. A palavra luva aparece três vezes. Assim, o último segmento - luva inerte no vento - sugere que a analogia caminha para uma fusão, culminância do processo que, trazendo perda de movimento, leva a mão a tornar-se "vestimenta", isto é, forma, aparência sensível de uma força que assim se oferece à vista. A capacidade de permanecer inerte no vento parece sustentar-se nessa força.

Uma torrente de associações pode ser gerada, a partir da analogia presente no poema de Jorge de Lima. Conforme Chevalier, o uso de luvas, na liturgia católica, e o de luvas brancas, na maçonaria, indiciam pureza (Chevalier; Gheerbrant, 1991, p.567). Colocada entre parênteses, a expressão "luva inerte no vento" sugere, sobretudo, estabilidade. Insere-se, na figura da mulher cuja mão tomba, um aspecto revelador da sua potencial estabilidade. Na substituição da imagem da mão pela imagem da luva, há sugestão de retirada do princípio anímico inerente à matéria viva, provocando sua inércia. A composição busca apreender a instantânea revelação desse processo de saída da vida, abandono da matéria mostrado como um êxtase letal e permeado por delícias. ${ }^{3}$ Todavia, dentro dessa percepção em que se vislumbra a transformação do corpo vivo em matéria inanimada, é também capturada a possibilidade de a visão estabilizar-se, na memória e no poema, possibilidade que está contida principalmente na sensação de inércia contrária à fluência em direção ao fim. O poema flagra, portanto, um processo que abarca tanto o declínio da matéria dirigindo-se à morte como a manifestação de uma força estabilizadora. Nesse sentido, a advertência dada ao leitor - "Olhai bem" - adquire especial importância. Mais do que a intensidade, o advérbio indica a qualidade necessária ao olhar, para que ele possa sur- 
preender, na materialidade da imagem poética (luva), algo que se revela na mão quase entregue à morte. Centrado na imagem da mulher que morre, o soneto comenta simultaneamente a passagem da vida material para a transcendência e a passagem da matéria para a arte.

Embora participe do processo geral de diluição, o rosto, ainda marcado pela vida, porta a dimensão de sensualidade e prazer que fica grifada pelo uso da palavra "delícias". Todo o quadro é contaminado pela "lindeza" atribuída a esse rosto surpreendido em hora crepuscular e integrado a um todo que se desfaz.

Os tercetos, no entanto, iniciam-se por uma adversativa. A partir dela, é posta em questão a natureza do vento, potência mais ativa, na "sala obscura". Situada logo no início da reflexão, a expressão "ninguém sabe" termina por aludir a um limite humano, no que tange à decifração dessa força atuante que permanece misteriosa. Podendo ser "hálito de Deus", o vento que age em meio à vida entregue ao destino letal pode também ser "uivo das potências adversas à criatura". Trazendo consigo o diálogo, essas últimas trazem o conflito, impondo à existência um teor dramático. Assim, embora carregado de delícia e lindeza, o quadro gera dúvida. Ainda que fascinada, a voz poética registra sua suspeita de que o mistério em torno da vida e da morte inclui agonia, tensão inerente ao confronto entre forças diversas. Em consonância com essa possibilidade, as imagens dos tercetos adquirem profunda ambivalência.

Embora a figura de cabelo ruivo participe de um destino de dissolução que não atinge o vento, os tercetos finais os entrelaçam nessa mesma área enigmática. Ele vai e vem, ela apenas vai, mas adquire a inércia, contaminando o olhar de quem a contempla. A rima uivo/ruivo fortalece, no nível sonoro, a aproximação entre a mulher e o vento. No nível imagético, essa proximidade é marcada pelo vento escondendo-se no cabelo ruivo. É novamente Chevalier a observar que, em torno da potencialidade simbólica inerente à cor vermelha, batalham vetores contrários: o fogo ctônico e o fogo uraniano, ação e êxtase, destruição e criação (Chevalier; Gheerbrant, 1991, p.944-6).

Estudando imagens que integram os "devaneios da morte", Bachelard destaca a morte de Ofélia. Tal como foi concebida por Shakespeare, a cena tornou-se emblema de um fim que envolve beleza, dando "ensejo a uma das mais claras sinédoques poéticas: os cabelos que se alongam, ao fluir da corrente". Segundo Bachelard (1989, p.86), a "cabeleira flutuante e desatada pelas ondas pode, isoladamente, explicar todo o complexo de Ofélia", indicando, por si só, "entrega à morte sem resistência, abandono da vida com beleza". Evocativo de elemento líquido, o termo "diluindo" aparece no início do poema, mas a imagem da água não chega a estar presente no $37^{\circ}$ soneto. Citada explicitamente no $48^{\circ}$ poema do livro, a imersão de Ofélia é aqui substituída por uma justaposição que dá, ao cabelo, a natureza aérea do vento.

Com a imagem do vento, Jorge de Lima traz ressonâncias simbólicas milenares, particularmente aquelas que integram tradições bíblicas. O toque no 
cabelo da mulher suscita a lembrança dos "Cânticos", em cujos versos o vento sopra sobre o jardim, metáfora do corpo da noiva. ${ }^{4}$ Com o ir e vir desse elemento que os versos finais indicam ser dotado de volição, o poeta traz um eco do Pentecostes, ocasião em que o Espírito Santo surge aos apóstolos como um "vento que sopra onde quer". Nos tercetos, são aludidos poderes de criação e destruição. Associado ao sopro criador, o vento pode ser tomado, em contexto bíblico, também como manifestação da ira divina.

Somente por divergirem entre si, as "potências" aludidas nos versos finais podem travar um diálogo "sem trégua". Essas forças têm em comum a adversidade mantida em relação às criaturas. Contendo um eco de Schopenhauer, a expressão parece privilegiar a Vontade metafísica que, segundo o filósofo, atua contra os indivíduos e os impulsiona a retornar para um estado de não individuação.

É compreensível que, escrevendo nos anos 1940, o poeta tenha tido sensação de dissolução generalizada. Concebidos na mesma época, os textos que integram Claro enigma, livro que Carlos Drummond de Andrade publicou em 1951, abrigam, no bojo de uma poética distinta, imagens de dissolvência, indicativas de um fim que apenas hesita, concentrando-se e permanecendo no $\operatorname{ar}^{5}{ }^{5}$ é, portanto, admissível que - não apenas para se inserir no diálogo com as formas tradicionais que marcou a poesia brasileira do período, mas sobretudo para expressar o seu sentimento de um mundo em diluição - Jorge de Lima tenha buscado fontes finisseculares, evocando vetores decadentistas e simbolistas. Como se sabe, dentro desse caldo cultural, o pensamento de Schopenhauer teve particular relevo. ${ }^{6}$ Ademais, se a poesia do autor alagoano opera contínuos deslocamentos, no que diz respeito às opções estéticas, ${ }^{7}$ seus romances insistentemente situam o interesse na realidade histórica e física, vindo do regionalismo de 1930, ao lado da busca de dimensões transcendentes, questão cara à estética simbolista.

Em síntese: o $37^{\circ}$ poema contido no Livro de sonetos concebe um cosmo atravessado por forças indecifráveis. Situada no centro desse cosmo, a mulher que morre funciona como um arco estendido entre delícias oferecidas aos sentidos e potências misteriosas que se manifestam e se escondem.

\section{A mão pendida}

Tal como apresentada no soneto, a visão da mão pendida e análoga à luva entra em estreita conexão com uma específica passagem do livro $A$ mulher obscura, publicado em 1939.

Com fortes componentes autobiográficos, o romance dedicado a J. Fernando Carneiro ${ }^{8}$ coincide, em algumas passagens, com as memórias que o poeta começou a publicar em capítulos, no Jornal de Letras, em 1952, e foram interrompidas com a sua morte, no ano seguinte. $\mathrm{O}$ enredo gira em torno de Fernando, cuja trajetória é dominada pela busca angustiada de uma mulher que ele próprio chama "a Bem-Amada". ${ }^{9}$ Englobando muito do cotidiano de uma pequena cidade nordestina, no começo do século XX, Jorge de Lima apresenta 
alguns tipos constitutivos de um meio provinciano - um juiz enganado pela esposa, um farmacêutico, um casal de estrangeiros, um padre, .... - e lugares decisivos para o convívio social em Santa Madalena: uma barbearia, uma farmácia, um bazar que se torna "foco de mexericos". Sem ordem cronológica, os diversos capítulos dão conta da vida de Fernando na cidade natal, das suas partidas e retornos ao lugar de origem.

A trama começa com uma cena transcorrida na propriedade do amigo Laécio. Trata-se de momento iniciatório, quando a beleza dos corpos femininos revela-se ao garoto que fica observando, às escondidas, mulheres negras banharem-se nas águas de um rio. Sem que a obsessão com a "Bem-Amada" resolvase, o romance caminha para o fim, depois da partida definitiva de Fernando. Tendo invadido o quarto da Sra. Brandt, esposa de um estrangeiro que viera gerenciar a fábrica de algodão, ele recebe o repúdio geral e é expulso. Como se vê, a imagem bíblica da Queda e a relação do protagonista com as mulheres são axiais no romance.

O título - a mulher obscura - constitui referência a uma presença feminina sem forma cuja força impulsiona o rapaz a desenvolver incessante pesquisa destituída de fruto. "Mais do que a soma de todas as mulheres", a "Bem-Amada" surge dentro de uma sensação de "alheamento" provocada por músicas capazes de criar "no mundo imperfeito..., um meridiano ou uma onda invisível, que não significa coisa alguma da vida, mas do mundo misterioso da morte" (Lima, 1959, p.141-2). Não podendo ser capturado pelos sentidos, esse mundo tornase obsessivo, pois fere a intuição, como força, e inquieta o intelecto, na condição de ideia.

Além da amada sem forma, surge uma série de figuras femininas. Entre elas, destacam-se Constança, "companheira de brinquedos" que depois se torna a noiva destinada a morrer ainda jovem; Hilda, a Sra. Brandt, amiga que, guardando semelhança física com a noiva falecida, torna-se alvo do desejo de Fernando; a própria mãe, cujo rosto é conhecido a partir de retratos; e a esposa do juiz, Irina, com quem Fernando tem ligação sexual. Cada uma dessas mulheres traz aspectos diversos da "Bem-Amada". Contudo, o inventário é hierárquico, uma vez levada em conta a maior ou menor proximidade com a mulher obscura. A mais próxima é Constança. Além de evocar a promessa de estabilidade que a jovem traz em si - como parte da sua afinidade com o mundo da morte e, consequentemente, como componente do encantamento que ela exerce sobre Fernando - o nome parece constituir uma alusão a Constanze Weber, que se casou com Mozart, tornando-se Constanze Weber Mozart. Afinal, ainda crianças, Fernando e Constança ficam fascinados com um minueto de Mozart que escutam numa velha caixa de música. $\mathrm{O}$ minueto funciona como um leitmotiv, marcando o destino dos parceiros. ${ }^{10}$

Em sua condição de noiva que se finda, Constança constitui um arco mediador entre a esfera da sensualidade e o mundo imaterial que preenche a morte 
e a transcendência. Nessa função mercurial, ela é seguida pela Sra. Yeats Brandt. ${ }^{11}$ Se a primeira representa a música, evocando a companheira de Mozart, a segunda evoca a poesia de Yeats. Há, portanto, implícito na hierarquia que orienta a apresentação das mulheres, um sistema igualmente hierárquico envolvendo as artes. Nesse sistema, o lugar mais alto - posto que mais capacitado a sugerir aos sentidos a presença da "Bem-Amada" - pertence à música, que se deixa seguir pela poesia. Assim, é por sua semelhança com a noiva morta que Hilda passa a exercer atração física, mas a sua cultura e maturidade agradam principalmente o intelecto de Fernando.

Como a "Bem-Amada" envolve Fernando sensual e espiritualmente, duas mulheres, privilegiando um dos polos, adquirem maior distância em relação a ela. Esses dois extremos são ocupados pelo retrato materno e por Irina. Distante de qualquer sensualidade, a mãe tem a face das vítimas, portando um sofrimento que desperta compaixão. Irina concentra em si um poder destinado ao desaparecimento, tão logo o ato carnal se consuma.

Ainda na infância de Fernando, o Padre Josué chega, em Sta. Madalena, trazendo consigo uma sobrinha que acompanha Fernando em seus brinquedos. Adulta, mas ainda muito jovem, Constança contrai tuberculose. Considerando que a moça não suportaria os dispêndios de energia que a paixão amorosa impõe, o sacerdote é contrário ao amor de Fernando e Constança. De fato, o rapaz - que se culpava pela morte da mãe, ocorrida por ocasião do seu nascimento, e também pelo nebuloso suicídio do pai - passará a culpar-se pela morte de Constança, depois de ter feito a moça experimentar os tormentos do ciúme e as tempestades de excitação sensual que, supostamente, apressaram o seu fim. Elaborado em primeira pessoa, o relato grifa a trajetória dolorosa de uma consciência obrigada a constatar, entre as marcas que vai deixando ao longo do seu percurso existencial, as pegadas da própria sombra. Desse modo, a questão da ambivalência no cerne do processo de existir, questão que ocupa os tercetos do $37^{\circ}$ soneto do livro de 1949 , tem proeminência no romance publicado dez anos antes.

A cena absorvida no Livro de sonetos surge no capítulo XXII. No final de uma festa, Fernando surpreende a noiva fatigada e sente que a sua morte não tarda:

Quando o baile estava no fim, e as primeiras estrelas, que assistem esmaecidas o aparecimento da madrugada, surgiram através das janelas, emprestando àquele final de festa essa fadiga comum aos velórios e aos festins, notei que aparecia atrás do reposteiro, junto à poltrona, uma das mãos que Constança deixara pender. Acometeu-me, de súbito, um arrepio de espanto, diante dos dedos alongados e do dorso daquela mão que parecia inanimada como a de uma luva e irreal como a de um anjo morto. Havia uma fadiga imensa no gesto dessa mão, que eu forçara a todas as obediências, a todas as renúncias, e que, no ângulo em que se encontrava, somente era visível (pois o restante do seu corpo estava oculto atrás do reposteiro), parecendo 
decepada, atirada do mistério de um outro mundo. Era certamente a mão cansada de um minueto em que o gesto lírico das notas agudas havia cedido à veemência das notas graves. Aquela mão pendida, na última frase da música interior, dolorosa como o pressentimento da morte, baixara para receber um beijo de agradecimento às suas resignações. (Lima, 1959, p.149-50)

Claramente, há intensa semelhança entre a cena narrativa e a visão instalada no centro do poema. Tão marcado pela fadiga quanto pode ser um velório, o final da festa entra em consonância com o crepúsculo que, no soneto, emoldura o ambiente e a figura de cabelo ruivo. ${ }^{12}$ Explicitado, o caráter inanimado da luva conota uma morte que se torna mais presente na ideia insólita do "anjo morto". Todavia, é possível considerar que uma passagem ilumina a outra, tanto a partir das suas semelhanças como por suas diferenças.

Nos dois enfoques do corpo feminino há privilégio dado à mão pendida. Na narrativa, a mão é explicitamente fragmento "decepado" de um todo. Em sua queda, o fragmento revela uma totalidade que não pode ser alcançada pelo olhar; pois o restante do corpo está “oculto atrás do reposteiro”. No poema, o mesmo princípio parece valer, mas não há referência ao corpo oculto, de modo que o leitor desliza quase imediatamente, da mão pendida, para a visão da luva inerte, provável expressão de algo que também se oculta.

Buscando antecedentes para o apreço que a poesia moderna dedica ao fragmento, Hugo Friedrich volta-se para o romantismo, e particularmente para o grotesco, cujos processos de fragmentação denunciavam o descompasso entre a percepção humana e a totalidade, e indicavam a necessidade de apreender essa totalidade, em partes que supostamente a condensavam. Segundo Friedrich (1978, p.33-4), essa teoria abriu caminho aos “absurdos mais modernos", especialmente à "finalidade obscura de indicar uma transcendência em dissonâncias e em fragmentos”.

O poema de Jorge de Lima sustenta-se na noção de que a transcendência pode ser apreendida em fragmentos reveladores. O soneto trai sensibilidade afinada com vertentes românticas, especialmente com alguns aspectos do romantismo tardio obcecado com a visão da decadência. ${ }^{13}$ "A mulher obscura" torna essa afinidade mais nítida.

No texto extraído do romance, a força transcendente do anjo pode ser "entrevista”, mas surge mesclada à morte, por imposição do vetor descendente que marca a mulher, em sua derradeira frase musical. Em contrapartida, o poema destaca a fixação que o fragmento consegue obter, ao tornar-se visão e imagem. Enquanto o romance grifa o declínio da vida, sem deixar de sugerir a dimensão angélica ligada à morte, o soneto destaca o mistério atuante em meio à vida em declínio e o olhar capaz de captar a capacidade de essa vida estabilizar-se.

A cena do romance é realmente uma lembrança, integra o passado do narrador. Figura próxima à Flora do romance machadiano, Constança não é a "Bem-Amada" imutável, justamente porque, a despeito do seu nome e da 
afinidade que ele assinala, ela é um ser transitório, noiva que "estava dentro da natureza e da vida” (Lima, 1959, p.53). Ao falar com Fernando, Padre Josué observa: "Você entreviu essa mulher obscura naquele corpo mais transitório que os outros". O drama interior de Fernando intensifica-se, não exatamente quando a noiva morre, mas quando o rosto da antiga companheira de brinquedos começa a desaparecer em sua memória, mesclando-se com outros rostos. Diante disso, ele fica obrigado a reconhecer, na instabilidade da lembrança, uma instabilidade que, sendo de Constança e de todas as formas vivas, também é sua: "Eu me sentia incapaz de reviver a figura de Constança porque já não podia reconstituir a minha própria figura fragmentada e móvel dentro de minha personalidade fugidia" (ibidem, p.205). Distanciando-se desse grifo posto na instabilidade, o poema ressalta a necessidade de que o olhar surpreenda o instante de revelação da inércia; o mesmo instante em que a visão, retirada do fluxo do tempo, pode tornar-se imagem poética. É na condição de imagem já fixada e isolada do fluxo temporal que o fragmento revela. Como uma forma ajustada à força, letra vestindo a alma, a luva evoca os princípios que regem a imagem poética, acrescentando, aos elementos constantes na cena do romance, uma explicitada consciência do próprio processo criativo e, consequentemente, da própria forma.

Evidentemente, a mulher que morre tem, na cena do romance, uma dimensão mais forte de pessoa. Trata-se de um indivíduo, com uma história. Vinda talvez de uma recordação, a figura do poema perde muito dessa dimensão pessoal, surgindo mais como componente de uma visão. É possível concluir que, enquanto a contemplação é, nessa específica cena narrativa, conduzida por um Eros voltado para a noiva, a contemplação que está no cerne da composição poética é dominada por um Eros que, voltado para o mistério, privilegia a visão da mulher que morre como imagem mais adequada à sua expressão. Afinal, amar a imagem da mulher fixando-se na forma do soneto é talvez a única maneira de amar, sensualmente, a bem-querida.

\section{A deliciosa veemência das notas graves}

Há, no cerne do $37^{\circ}$ soneto, uma sensibilidade erótica. O leitor é desafiado a participar do ato contemplativo, envolvendo-se com pelo menos três aspectos que, em maior ou menor grau, integram esse Eros substancial à composição do poema; são eles: o amor pelo processo de entrega à morte; o amor pela mulher; e o amor pela visão capaz de estabilizar-se como imagem poética.

Composto pelo vento que vai e vem, e mais por uma série de elementos que se direcionam ao próprio fim, o complexo de imagens existente no poema coincide talvez a uma lembrança. Todavia, a lembrança é aqui vista com sentidos que extrapolam os limites do passado individual. No âmbito desse penúltimo livro do poeta, as imagens que têm suporte no passado tendem a obter um preenchimento de sentido, ${ }^{14}$ de modo que passam a representar, além de si próprias, um mundo arquetípico e sagrado. Assim, a sala cuja porta se abre à ação do vento constitui um espaço físico e simultaneamente um cosmo. Dentro 
desse cosmo, a vida é focalizada por uma percepção que surpreende e destaca o momento de declínio, e mais a lindeza inerente ao declínio.

Se recorrermos à célebre lição de Croce e discernirmos, inerente ao complexo de imagens, o sentimento que o anima, constatamos que a percepção da cena é impulsionada pela melancolia, "sentimento por excelência da mudança das formas no correr do tempo", conforme formulação precisa de Alfredo Bosi. ${ }^{15}$ Mas se à melancolia deve ser atribuído esse enfoque fixo sobre a diluição de tudo, há, por outro lado, fascínio. E também há, compondo esse fascínio, prazer sensual obtido pelo olhar.

Segundo o Dicionário de Morais (s. d.), lindo é qualidade que agrada a vista e o espírito. A beleza impressa no rosto da mulher impregna todo o cosmo que a abriga, agradando aquele que a vê. Contudo, somente um olhar que se compraz na contemplação do processo de diluição das formas vivas torna-se capaz de atestar a persistência de delícias no decurso desse processo. A voz que fala no soneto incita o leitor a participar do seu deleite que tem bom convívio com a melancolia. Em alguma medida, o olhar solicitado deverá assemelhar-se àquele que mantém Isolda, quando, nas passagens finais do libreto escrito por Wagner, delicia-se com os elementos da morte exibidos no olho ainda aberto de Tristão. E assim como Jorge de Lima dirige-se aos leitores, a Isolda wagneriana pede aos companheiros que se integrem ao quadro: "Leve e grácil/ quando ele ri/ enquanto aberto/mantém o olho:/ Amigos, ele os/Vê? Não os viu?". ${ }^{16}$

Ao comentar essa segunda representação do êxtase contida no libreto de Wagner, ${ }^{17}$ Leo Spitzer (2003) destaca o fato de que, executando uma descida assinalada pela música, Isolda é movida pelo anseio de dissipar-se, do mesmo modo que o amante dissipou-se em um todo governado por forças violentas. No libreto, o espírito do mundo surge na forma de massas turbulentas. Em sua análise, Spitzer (2003, p.89) observa: "No sistema wagneriano, o espírito do mundo, figurado como "sopro do mundo" (Welt-Athem), identifica-se ao conjunto do universo (das All). Já não é o "espírito de Deus" que sopra sobre as águas, mas sim Deus sive natura [Deus ou a natureza]". Ao identificar esse agente - "o sopro" (Athem) -, Spitzer salienta a perspectiva de Wagner que, como bem notou Nietzsche, tem débito com o pessimismo de Schopenhauer. ${ }^{18}$ O olhar que tomasse tal direção estaria privilegiando, na ação do vento, "as potências adversas à criatura".

Em sua análise, Spitzer (2003) confronta a representação do êxtase feita por Wagner com outro tipo de experiência extática: o movimento ascendente para Deus, presente no poema "En una noche oscura", escrito por San Juan de la Cruz. O confronto construído no discurso analítico de Spitzer ajuda a entender o dilema exposto nos tercetos do poema escrito por Jorge de Lima.

Do apreço pela diluição das formas, participa o alívio prazeroso vindo com o fim de toda resistência oferecida ao poder da Vontade metafísica pensada por Schopenhauer. Como componente outro - e igualmente adverso às criaturas 
- pode haver também anseio de retorno ao magma vivo e pulsante da matéria não individuada. Nesse último caso, a entrega à morte coincide ao amor fati, tal como pensado por Nietzsche. No entanto, além desses dois vetores tensamente próximos, marca o $37^{\circ}$ soneto do livro um prazer espiritual, que pode ser entendido como satisfação dada às expectativas de entregar-se a Deus. Santo Agostinho preconiza que a vida é conduzida por Deus, a cujo designo o homem, seguindo o exemplo de Cristo em hora final, ${ }^{19}$ deve entregar-se. Sem abrir espaço à negação da metafísica contida no pensamento de Nietzsche, a voz poética hesita, nos tercetos, entre a visão de Schopenhauer e aquela que Agostinho apresenta em sua Cidade de Deus. Enquanto a óptica de Schopenhauer destaca, na ânsia de repouso, manifestação da Vontade que determina regresso ao informe, Agostinho fala de entrega à divindade. Foi a esse abandono ao propósito divino que Agostinho chamou "amor fati".

Embora constituam polaridades de uma tensão, as perspectivas convergem em direção ao amor pela entrega à morte, processo vivido vicariamente através do olhar. É então necessário admitir que, atingido pela vivência de duas guerras, o poeta expôs afinidade com alguns aspectos da cultura finissecular e com os rastros que suas tendências artísticas deixaram no século XX. ${ }^{20}$ Ao mesmo tempo, é também preciso notar que essas afinidades estão, no Livro de sonetos, a serviço da perspectiva religiosa que ali predomina e confere coesão aos diversos níveis das composições.

Embora, em seu $37^{\circ}$ soneto, Jorge de Lima não fale, como Juan de la Cruz, de uma aventura realizada pela alma em demanda da união com Deus, sua cena expõe uma letargia que, na visão cristã, constitui acolhimento dado ao designo divino. Posta sob esse prisma, a inércia da luva torna-se indicativa do fim de todo esforço para resistir ao chamado de Deus. No mesmo caminho, a cor ruiva do cabelo sugere a condição inflamada da mulher já exposta ao hálito sagrado.

De fato, as perspectivas postas em tensão nos tercetos já se mesclavam na cultura finissecular. O cristianismo alimentou o imaginário decadentista e simbolista, fornecendo-lhe referências recorrentes, como São Sebastião e Salomé. Comentando aspectos contidos na arte de Gustave Moreau, Mário Praz referese à bela Inércia como um dos princípios que o pintor proclamava, propagando que o captara "nos profetas, nas sibilas e nas alegorias sepulcrais de Michelangelo". ${ }^{21}$ Ligado ao motivo da "morte fascinante", Moreau teria declarado que celebrara "a glorificação dos sacrifícios e a apoteose dos redentores" (Praz, 1996, p.273). No entanto, no que tange ao olhar direcionado à mulher, Jorge de Lima afasta-se substancialmente da postura mais comumente adotada pelos artistas da decadência, ficando mais próximo de correntes místicas do simbolismo. ${ }^{22}$ Fixado na beleza feminina, o decadentismo tendeu a apresentar a mulher como imagem do Mal. Em seu fascínio, o poeta brasileiro situa primordialmente, na mulher, uma capacidade de dar acesso às fontes sagradas. 
A "bem-querida" apresenta afinidade com a Beatriz, de Dante, particularmente em "A vida nova". Jorge de Lima nutre-se de um aspecto visionário que, vindo de Dante, enraíza-se, segundo Auerbach, "no motivo cristão oriental da perfeição encarnada". Mas, tal como aparece no Livro de sonetos, a amada é desprovida dos aspectos que levaram o mesmo Auerbach (1997a) a enxergar Dante como um poeta do mundo secular, terreno. Segundo Auerbach (1997a), mesmo se considerada como "figura alegórica que representa a sabedoria mística, Beatriz incorpora tal soma de realidade pessoal, que temos o direito de considerá-la um ser humano”. Justamente essa dimensão existencial e humana tende a ausentarse, na composição da bem-querida presente no livro publicado em 1949. ${ }^{23}$

O lugar privilegiado concedido à mulher tem, na literatura em língua portuguesa, momento marcante com Menina e moça, de Bernardim Ribeiro. Helder Macedo observa que, para o escritor do Alentejo, a mulher está mais próxima da divindade do que o homem. Segundo a leitura de Macedo (1999), para Bernardim, compreender a afinidade da mulher com Deus equivaleria a conhecer Deus. Essa noção embebida de um caldo cultural gnóstico e neoplatônico já orientara a doutrina do amor cortês e a poesia trovadoresca a ela ligada, persistira nos poetas do dolce stil nuovo e fora vivificada na escrita de Dante. Alimentados pelo culto a Maria, esses rios fluíram por muitos caminhos antes de tomarem a direção do Livro de sonetos. É ainda necessário lembrar que o surrealismo deu, no século XX, novo relevo e novas formas ao enfoque da intimidade existente entre o mistério e a mulher, com sua propensão à revelação.

Conta Alexandrian (1977, p.205-55) que, ao visitar, ainda adolescente, o Museu Gustave Moreau, Breton ali descobriu a essência secreta da feminilidade, julgando que experimentaria a mais extrema felicidade, se encontrasse uma mulher como aquelas pintadas nos quadros. Mais tarde, o mesmo Breton e outros surrealistas apregoaram a maravilha dos encontros extraordinários. Nesses encontros - em que o homem deveria encontrar e a mulher deveria ser encontrada - a figura feminina constitui enigma vivo, que cabe ao artista decifrar Ismael Nery - que, em Paris, teve contato com Breton e com Marc Chagall - conferiu um caráter profundamente religioso e universalista às figuras femininas que criou em sua pintura e cantou em sua poesia. Ligados a Nery, Jorge de Lima e o seu contemporâneo Murilo Mendes deram, cada um a seu modo, marcas próprias a essa visão da mulher como súmula dos mistérios inerentes a toda criação.

Finalmente, é preciso insistir que, no Eros atuante na composição do soneto, há amor pela imagem poética e amor pela forma do soneto, ela própria um emblema de fixação, estabilidade, inércia. Esse afeto volta-se também para o olhar do poeta, capaz de paralisar a vida, como uma espécie de medusa. Num tempo em que o mito da velocidade e a dinâmica do progresso já tinham expostos os seus limites, e tinham mesmo se revelado promotores de desastres e absurdos, a ânsia por inércia e por constância pode ser entendida como mais um modo de fazer contraposição ao fracasso histórico. Essa contraposição que 
engloba o amor pelo êxtase e pela condição estática dos mortos certamente também abarca o amor pela imagem poética e pela forma fixa do soneto, substratos corpóreos da bem-querida, que é "sonâmbula parada", "laguna quieta, viva e impossível".

\section{Notas}

1 Quando dá início à série de sonetos centrada na figura feminina da amada, o poeta focaliza o interior de uma casa onde as flores ressecam. No texto, ele usa o termo "bem-querida", para designar a antiga habitante da morada, luminosa e ausente. Cf. "Na alcova em que viveu a bem-querida/ se esvaem gestos..." .

$2 \mathrm{O}$ Livro de sonetos permite o estabelecimento de nexos não lineares entre os poemas. Se o $33^{\circ}$ soneto apresenta uma casa vazia, o $37^{\circ}$ traz sua sala preenchida pela visão da mulher que se entrega à morte.

3 Lembro que, no termo grego "ekstasis", há o sentido de "saída, partida".

4 "Desperta, vento norte,/ chega-te, vento sul,/ soprai sobre meu jardim/ e espalhai os seus perfumes." Cito tradução feita por Geraldo Holanda Cavalcanti (2005, p.235).

5 Cito implicitamente versos do poema "Dissolução", que inicia Claro enigma (Drummond de Andrade, 1988): “Um fim unânime concentra-se/ e pousa no ar. Hesitando". Exemplar no que diz respeito às imagens portadoras de dissolvência é o poema "Morte das casas de Ouro Preto".

6 Cf. "Dans le milieu symboliste, les philosophes en vogue étaient Hegel et Schopenhauer, qui présentent tous deux une composante néoplatonicienne non négligeable" (Lucie-Smith, 1999, p.12).

7 Partindo das formas afinadas à escrita parnasiana e adotadas nos XIV Alexandrinos que deram início ao seu percurso poético, Jorge de Lima desloca-se para uma adesão franca ao modernismo, absorvido sob a feição de proximidade com a realidade regional, rica em vitalidade, crenças e ritos. Na década de 1930, o poeta aderiu a um movimento em defesa do catolicismo, publicando, em parceria com Murilo Mendes, Tempo e eternidade, volume de poemas escritos sob o lema de "restaurar a poesia em Cristo". Depurada, a intenção manteve-se em A túnica inconsútil. Todavia, embora os motivos bíblicos e a inspiração cristã prossigam, como fortes alicerces da sua poesia, os livros seguintes - Anunciação e encontro de Mira-Celi, O livro de sonetos e Invenção de Orfeu - dão máxima ênfase a uma diretriz que, no início, se manifestava de modo mais contido. Identificada por Alfredo Bosi (1979, p.502-8) como uma força de coesão exercida sobre os variados caminhos estéticos do poeta, essa diretriz, que nos últimos livros se fortalece, pode ser compreendida como empenho para descer "às fontes da memória e do inconsciente", vocação para realizar sondagens no mundo interior.

8 José Fernando Carneiro é autor de “Apresentação de Jorge de Lima”. Publicado inicialmente pela Imprensa Nacional do Livro, o trabalho, contendo trechos de natureza biográfica, foi ampliado na edição da Agir (cf. Carneiro. 1958).

9 O romance adota grafia com maiúsculas: Bem-Amada.

10 Cf. “[...] os compassos da pequena caixa de música perdida no passado, constante, como um leitmotiv, nos momentos mais emocionais da minha vida, surgiram e cresceram, como uma absorvente realidade" (Lima, 1959, p.150). 
11 O nome do esposo de Hilda é provavelmente uma homenagem ao autor de "Sailing to Byzantium", poema publicado em 1928 e centrado na busca de uma vida espiritual. O poeta irlandês teve ligações várias com o ocultismo. Segundo Péricles Eugênio da Silva Ramos, Yeats foi introduzido na Ordem da Aurora de Ouro, grupo ligado à magia, por Constance, esposa de Oscar Wilde (cf. Yeats, 1987).

$12 \mathrm{O}$ romance parece seguir o esquema da alba medieval, privilegiando a noite como hora da festa, em detrimento do amanhecer.

13 Como designação das várias vertentes decadentistas, a expressão "romantismo tardio" é justificada, à saciedade, por Mário Praz (1996).

14 A noção de preenchimento surge aqui com o significado dado por Auerbach, ao falar do método de interpretação figural: "a interpretação figural estabelece uma conexão entre dois acontecimentos ou duas pessoas, em que o primeiro significa não apenas a si mesmo, mas também ao segundo, enquanto o segundo abrange e/ ou preenche o primeiro" (cf. Auerbach, 1997b, p.46).

15 Em análise do poema "Anoitecer", escrito por Raimundo Correia (cf. Bosi, 1996, p.223).

16 Cito tradução feita por Haroldo de Campos para: "Mild und leise/ wie er lächelt,/ wie das Auge/ hold er öffnet: / seht ihr, Freunde, / säh't ihr's nicht /" (Spitzer, 2003, p.27).

17 A primeira é o êxtase obtido no amor, quando ingerido o filtro mágico.

18 Sobre a ópera Tristão e Isolda, de Wagner,e suas relações com a história da literatura amorosa no Ocidente (cf. Wisnik, 1987, p.195-28).

19 Conforme o Evangelho de São Lucas: "Pai, nas tuas mãos, eu entrego o meu espírito".

20 Entre esses rastros, Mário Praz (1996, p.19-20) situou o Sous le soleil de Satan, de Bernanos, e Moderato cantabile, de Marguerite Duras.

21 O outro princípio era o da Riqueza necessária (cf. Praz, 1996, p.265).

22 Penso, por exemplo, no movimento Rose+Croix que, orientado por Péladan e por seus discípulos, chegou a ter alguma repercussão em Apollinaire.

23 Jorge de Lima excluiu 17 sonetos amorosos, por achar que não sintonizavam com o espírito geral do volume. Nesses poemas excluídos, insinuam-se traços pessoais (cf. Lima, 1958, 986-95).

\section{Referências}

ALEXANDRIAN. André Breton et l'amour surréaliste. In: Les libérateurs de l'amour. Paris: Seuil, 1977.

AUERBACH, E. Dante, poeta do mundo secular. Rio de Janeiro: Topbooks, 1997a. Figura. São Paulo: Ática, 1997b.

BACHELARD, C. O complexo de Caronte. O complexo de Ofélia. In: . A água e os sonhos: ensaios sobre a imaginação da matéria. São Paulo: Martins Fontes, 1989.

BOSI, A. Dois momentos. In: . História concisa da literatura brasileira. São Paulo: Cultrix, 1979. 
BOSI, A. A intuição da passagem em um soneto de Raimundo Correia. In: (Org.)

Leitura de poesia. São Paulo: Ática, 1996.

CARNEIRO, J. F. Apresentação de Jorge de Lima. Rio de Janeiro: Agir, 1958.

CAVAlCANTI, G. H. O Cântico dos Cânticos: um ensaio de interpretação através de suas traduções. São Paulo: Edusp, 2005.

CHEVALIER, J.; GHEERBRANT, A. Dicionário de símbolos. Rio de Janeiro: J. Olympio, 1991.

DRUMMOND DE ANDRADE, C. Claro enigma. In: Poesia e prosa. Rio de Janeiro: Nova Aguillar, 1988.

FRIEDRICH, H. Estrutura da lírica moderna: da metade do séc. XIX a meados do séc. XX. São Paulo: Duas Cidades, 1978.

LIMA, J. de. Obra completa. Rio de Janeiro: J. Aguillar, 1958. v.1.

A mulher obscura: romance. Rio de Janeiro: Agir, 1959.

LUCIE-SMITH, E. Le symbolisme. Paris: Thames\&Hudson, 1999.

MACEDO, H. Do significado oculto da menina e moça. Lisboa: Guimarães, 1999.

MORAIS, A. de. Edição compacta do texto fundamental do Grande Dicionário da Língua Portuguesa de Antonio Morais e Silva. V.II. Lisboa, Confluência/ Rio de Janeiro, Biblioteca Luso-Brasileira. p. 1391.

PRAZ, M. A carne, a morte e o diabo na literatura romántica. Campinas: Unicamp, 1996.

SPITZER, L. Três poemas sobre o êxtase. São Paulo: Cosac \& Naify, 2003.

YEATS, W. B. Poemas. Edição bilíngue com trad. e introd. de Péricles Eugênio da Silva Ramos. São Paulo: Art, 1987.

WISNIK, J. M. A paixão dionisíaca em Tristão e Isolda. In: NOVAES, A. (Org.) Os sentidos da paixão. São Paulo: Cia. das Letras, 1987.

RESUMO - Análise de poema contido no Livro de sonetos, publicado em 1949, por Jorge de Lima. Partindo de uma "leitura rente ao texto", a reflexão chega à prática comparativa, confrontando o poema a uma passagem do romance $A$ mulher obscura, de 1939. Por último, há o enfoque do amor contido nos dois textos. Destacam-se o amor pela forma do soneto e o amor pela "mulher que se entrega à morte", imagem que, portando rastros de tendências finisseculares, adquire marcas impressas pelo autor alagoano.

PALAVRAS-CHAVE: Jorge de Lima, Poesia brasileira, Anos 1940, Imagem poética, Amor. ABSTRACT - Analysis of a poem from Livro de sonetos, published in 1949 by Jorge de Lima. Beginning with a "close reading of the text," the reflection becomes a comparative practice, confronting the poem with a passage from the 1939 novel $A$ mulher obscura. Finally, it focuses on the love found in both texts, highlighting the love for the sonnet form and the love for "woman who delivers herself unto death" - an image that, 
with evident fin-de-siècle traces, is finely imprinted by the author from Alagoas.

KEYWORDS: Jorge de Lima, Brazilian poetry, 1940s, Poetic image, Love.

Mirella Márcia Longo é professora da pós-graduação em Literatura e Cultura da Universidade Federal da Bahia. Pesquisadora do CNPq, pós-doutoranda na Universidade de São Paulo. @- mimlvl@yahoo.com.br

${ }^{\text {I } U n i v e r s i d a d e ~ F e d e r a l ~ d a ~ B a h i a, ~ S a l v a d o r / B a h i a, ~ B r a s i l . ~}$

Recebido em 25.3.2015 e aceito em 19.4.2015. 